СУТНICНО-ЗМІСТОВА ХАРАКТЕРИСТИКА ОРГАНІЗАЦІЙНО-ЕКОНОМІЧНОГО МЕХАНІЗМУ РОЗПОДІЛУ
ФІНАНСОВИХ РЕСУРСІВ ОБ'ЄДНАНОЇ ТЕРИТОРІАЛЬНОЇ ГРОМАДИ:
ПОРІВНЯЛЬНО-АНАЛІТИЧНИЙ ПІДХІД У КОНТЕКСТІ БЕЗПЕКОЗНАВСТВА

\title{
ESSENTIAL INTENTIONAL CHARACTERISTICS \\ OF ORGANIZATIONAL AND ECONOMIC MECHANISM OF DISTRIBUTION OF FINANCIAL RESOURCES OF UNITED TERRITORIAL COMMUNITY: A COMPARATIVE-ANALYTICAL APPROACH IN THE CONTEXT OF SECURITY
}

УДК 330.161:658.012.8

https://doi.org/10.32843/infrastruct36-5

\section{Вівчар О.І.}

д.е.н., доцент,

професор кафедри економічної безпеки та фрінансових розслідувань

Тернопільський національний економічний університет

Редьква 0.3.

к.е.н., викладач

Технічний коледж

Тернопільський національний

технічний університет

імені Івана Пулюя

Гарматюк 0.O.

к.е.н., доцент кафедри менеджменту

та адміністрування

Тернопільський національний

технічний університет

імені Івана Пулюя

\begin{abstract}
у статmі розелянуто низку сучасних проблем використання бюджетних коштів на регіональному рівні та визначено таку економічну категорію, як «фрінансова децентралізація». Здійснено пошук джерел наповнення та раціонального використання місчевого бюджету. Встановлено, що розподіл бюджетних коштів у територіальній громаді здійснюється залежно від площі території, чисельності сільських жителів, а також фактичних доходів села за відповідний період. Підкреслено необхідність дотримання принципу публічності та прозорості на практиці. Підтверджено, що ефективності ресоорм орінансової децентралізаціі можливо досягнути за умови одночасноі зміни окремих їі складників, а саме: проведення бюджетної, податкової, адміністративно-територіальної ресрорм; реформування місцевих органів представницько та виконавчої влади на місцях; підвищення ролі малого і середнього підприємництва в ресьормуванні місцевої економіки.

Ключові слова: децентралізація, економічна безпека, об'єднані територіальні громади, розподіл місцевих бюджетів, бюджетні кошти, міжбюджетні відносини, бюджетна децентралізація
\end{abstract}

В статье рассмотрен ряд современныхпроблем использования бюджетных средств на региональном уровне и определена такая экономическая категория, как «фринансовая децентрализация». Осуществлен поиск источников наполнения и рационального использования местного бюджета. Установлено, что распределение бюджетных средств в территориальной общине осуществляется в зависимости от площади территории, численности сельских жителей, а также фрактических доходов села за соответствующий период. Подчеркнута необходимость соблюдения принципа публичности и прозрачности на практике. Подтверждено, что эфффективности реформы фринансовой децентрализации можно достичь при условии одновременного изменения отдельных ее составляющих, а именно: проведения бюджетной, налоговой, административно-территориальной реформ; рефрормирования местных органов представительной и исполнительной власти на местах; повышения роли малого и среднего предпринимательства в реформировании местной экономики.

Ключевые слова: децентрализация, экономическая безопасность, объединенные территориальные общины, распределение местных бюджетов, бюджетные средства, межбюджетные отношения, бюджетная децентрализация.

The article considers a number of current problems of using budget funds at the regional level and defines such economic category as «financial decentralization». It is shown that the distribution of budget funds in the territorial community is made depending on the area of the territory, the number of rural residents and the actual income of the village for the corresponding period. Since transparency is a basic condition for introducing a new type of relations between citizens and executive authorities, in which each person would be assured of real observance and protection of his/her rights and freedoms, the urgency of the problem of transparency of actions of authorities of all levels was emphasized. The investigation showed that, depending on how the budget of the self-government unit is formed, which is the control over the execution of the budget, it is possible to say how complete the self-government system is. Increasing public involvement in local budget processes and the functioning of the service delivery system offers a number of benefits to government, as well as, to citizens. It is highlighted that compliance with the principle of transparency in practice is a guarantee of budgetary security, as it ensures public confidence in the governmental budgetary policy of the government and increases the efficiency of public and govermental control over public finances. It is confirmed that the effectiveness of financial decentralization reform can be achieved provided that its individual components are changed simultaneously, namely: budgetary, tax, administrative-territorial reforms; reform of local bodies of representative and executive power on the ground; enhancing the role of small and medium-sized enterprises in reforming the local economy. It is pointed out that prospective directions of further research in this direction are to invistigate the question of the current state and prospects of development of the aforementioned components of financial decentralization, taking the best practices of EU countries and the possibilities of its application in national practice.

Key words: decentralization, economic security, united territorial communities, distribution of local budgets, budgetary funds, intergovernmental relations, budgetary decentralization.

Постановка проблеми. На сучасному етапі становлення української державності 3 вибором європейського курсу актуальності набуває питання бюджетної децентралізації, де ключовими фрігурами $є$ ефективність діяльності органів місцевого самоврядування. У зв'язку з цим постає проблема оптимального перерозподілу фінансових ресурсів та повноважень органами місцевої влади, які нині $€$ основними та найбільш актуальними для під- вищення ефрективності бюджетної системи загалом, адже дієвість соціально-економічної політики держави та її економічна безпека безпосередньо залежать від раціонально побудованої та збалансованої системи економічних відносин, чіткого перерозподілу фрінансових ресурсів та гнучкості способів їх використання.

Надмірна централізація повноважень органів виконавчої влади та відповідних фрінансово- 
матеріальних ресурсів для їхнього здійснення, що мала місце в Україні до 2015 р., зумовила необхідність проведення реформ за принципом децентралізації з наданням значних повноважень територіальним громадам, наділенням їх більшими ресурсами задля місцевого розвитку. При цьому саме фрінансову децентралізацію було спрямовано на забезпечення спроможності органів місцевого самоврядування самостійно, щоб громада за рахунок власних ресурсів мала змогу вирішувати питання місцевого значення. Водночас перші роки реалізації бюджетної реформи з одночасним проведенням добровільного об'єднання територіальних громад засвідчили про наявність немалих проблем щодо фрормування місцевих бюджетів та здійснення видаткових повноважень.

Проблеми місцевих бюджетів завжди були в центрі уваги таких науковців і фрахівців, як: О. Василик, Я. Казюк, В. Кравченко, О. Кириленко, І. Луніна, В. Мамонова, К. Павлюк, І. Чугунов, C. Юрій та ін. Їхні публікації присвячено дослідженням питань бюджетної системи України загалом та бюджетного процесу і міжбюджетних відносин, теоретико-прикладних засад управління публічними ресурсами зокрема. В останні роки виконується багато аналітичних досліджень, що базуються на скануванні моніторингу процесу «Напрями реформування системи місцевого самоврядування в Україні», «Теорія та практика державного управління 4(59)/2017 децентралізації влади та рефрормування місцевого самоврядування», який регулярно проводиться Міністерством регіонального розвитку, будівництва та житлово-комунального господарства України [5].

Аналіз останніх досліджень і публікацій. Окремі питання механізму розподілу фрінансових ресурсів в об'єднаних територіальних громадах висвітлено у працях багатьох вітчизняних науковців. Серед найбільш вагомих напрацювань бюджетної децентралізації та безпекознавства можна виокремити праці таких фрундаментальних учених та практиків, як: С. Буковинський, Г. Возняк, О. Зварич, О. Кириленко, С. Кондратюк, І. Патока, Л. Тарангул, Н. Мєуш та багато інших. Дослідники значну увагу приділяють фрормуванню міжбюджетних фрінансових потоків, фрінансовому забезпеченню об'єднаних територіальних громад, перевагам та ризикам бюджетної децентралізації, напрямам розширення доходів місцевих бюджетів.

Водночас, незважаючи на зростання кількості наукових публікацій у цій сорері, питання ефективності фрінансової децентралізації потребує подальшого поглибленого вивчення у зв'язку зі фрагментарністю дослідження проблематики теоретичних, еволюційних і практичних аспектів, недосконалості та постійних змін податкового та бюджетного законодавства, що й зумовлює актуальність і практичну значущість дослідження
3 питань фрінансової децентралізації з урахуванням інтересів як центральних органів влади, органів місцевого самоврядування, так і представників територіальних громад.

Виділення не вирішених раніше частин загальної проблеми. Оскільки реформа фрінансової децентралізації ще не завершена, не вирішена проблема оптимізації, нерозв'язаною залишається проблема оптимізації дохідної і видаткової частини місцевих бюджетів із погляду економічної безпеки, очевидною $€$ потреба проведення подальших наукових досліджень у напрямі порівняльно-аналітичних підходів у контексті безпекознавства та механізму розподілу фрінансових ресурсів об'єднаних територіальних громад. Все це зумовлює необхідність проведення аналізу й дослідження сучасних тенденцій щодо незбалансованості та виокремлення основних проблем використання бюджетних коштів на регіональному рівні.

Постановка завдання. Метою статті $€$ дослідження сучасних проблем використання бюджетних коштів на регіональному рівні, а саме: визначення такої економічної категорії, як «фрінансова децентралізація», пошук джерел наповнення та раціонального використання місцевого бюджету, що в перспективі покращить соціальне становище у регіоні.

Виклад основного матеріалу дослідження. Впродовж 2015-2016 рр. в Україні відбулися фрундаментальні зміни системи місцевого самоврядування, особливо в частині фрормування місцевих бюджетів та утворення нового потужного суб'єкта місцевого самоврядування - об'єднаних територіальних громад (ОТГ). Нові ОТГ отримали значні фрінансові ресурси, а державна підтримка розвитку інфрраструктури таких громад дала імпульс для створення у сільських територіях нових можливостей для отримання людьми повноцінних послуг від місцевого самоврядування, яких вони раніше були позбавлені. Субвенція покриває такі питання, як: адміністративні послуги, будівництво та ремонт доріг, реконструкція будівель, закупівля транспорту, зокрема для підвезення дітей до школи тощо. Але потрібно зазначити, що влада залишила за собою право впливу на розподіл коштів, і хоча ОТГ вже «мають» закладені на них кошти (і знають про їх обсяг), але узгоджують їх використання, тому вплив центральної влади та можливість нераціонального використання коштів самими ОТГ тут мінімізовано, і завжди залишається можливість скоригувати використання коштів.

Отримання нових повноважень та відповідних фрінансових ресурсів поставило перед органами місцевого самоврядування ОТГ та депутатами відповідних рад нові завдання щодо планування та використання бюджетних надходжень.

Окремі види доходів і видатків бюджету можуть перетворюватися у бюджетні стимули, 
якщо методи мобілізації, напрями і порядок використання бюджетних коштів будуть пов'язані з інтересами громади та економічними інтересами суб'єктів господарювання.

Бюджетний кодекс України встановлює, що одним із принципів бюджетної системи є принцип публічності та прозорості, який передбачає інорормування громадськості 3 питань складання, розгляду, затвердження, виконання державного бюджету та місцевих бюджетів, а також контролю за виконанням державного бюджету та місцевих бюджетів (ст. 7 Кодексу).

Плануючи розвиток інфрраструктури громади, дуже важливим і ключовим є виявлення реальних потреб жителів, бачення проблем їхніми очима, визначення пріоритетів у вирішенні тих чи інших проєктів. Саме тому в об'єднаній територіальній громаді $€$ необхідність вирішити проблему справедливого розподілу бюджетних коштів між населеними пунктами, що ввійшли до складу об'єднаної громади. Розв'язати цю проблему необхідно колегіально, на основі запропонованого першого проекту організаційноекономічного механізму розподілу фрінансових ресурсів об'єднаної територіальної громади, при цьому сума бюджету розвитку затверджується радою громади.

3 метою дотримання рівноправності та фрінансової самостійності під час створення фрормули розподілу бюджету розвитку села (селища) до уваги взяли такі поняття, як бюджетний розвиток громади (B), загальні доходи села (селища) (Q); кількість населення громади (n); доходи на одного жителя громади (q); доходи на одного жителя села (селища) (qo); коесріцієнт економічної спроможності села (селища) $(K)$; середній дохід на одного жителя села $\left(q_{s}\right)$.

ПРОЕКТ 1: Алгоритм розрахунку бюджету кожного села (селища) включає наступні етапи:

$$
q_{o}=Q / n,
$$

де $q_{o}$ - доходи на одного жителя села (селища);

Q - загальні доходи села (селища);

$n$ - кількість населення громади

$$
q=B / n,
$$

де $q$ - доходи на одного жителя громади;

$B$ - бюджетний розвиток громади;

$n$ - кількість населення громади.

$$
q_{s}=\sum q_{o} / v,
$$

де $q_{s}$ - середній дохід на одного жителя села; $v$ - кількість сіл у громаді (18 сіл (селищ)).

$$
K=q_{o} / q_{s}
$$

де $K$ - коефіцієнт економічної спроможності села (селища)

$$
B^{\prime}=q * K{ }^{*} n,
$$

де $B^{\prime}$ - бюджет розвитку села (селища) на бюджетний період.
На основі проведених досліджень нами сорормовано другий проєкт організаційно-економічного механізму розподілу фрінансових ресурсів об'єднаної територіальної громади, який описано нижче та обґрунтовано відповідно.

3 метою дотримання рівноправності та фрінансової самостійності під час створення фрормули розподілу бюджету розвитку села (селища) до уваги взяли такі поняття, як бюджетний розвиток громади (B), бюджет розвитку села (селища) (B); кількість населення громади $(N)$; кількість населення села (селища) (n); витрати на 1 жителя села (селища) (qо); коефіцієнт економічної спроможності села (селища) (K); коефріцієнт стимуляції збільшення доходів $\left(K_{s}\right)$; дохід села (селища) за відповідний період $\left(Q_{f}\right)$.

ПРОЄКТ 2: Алгоритм розрахунку бюджету села (селища) включає такі етапи:

$$
B^{\prime}=n * q_{o}
$$

де $B^{\prime}$ - бюджет розвитку села (селища) на бюджетний період;

$$
\begin{aligned}
& n-\text { кількість населення села (селища); } \\
& q_{\text {o }} \text { - витрати на 1-го жителя села (селища). }
\end{aligned}
$$

$$
q_{\mathrm{o}}=B / N \text {, }
$$

де $B$ - бюджет розвитку громади на бюджетний період;

$$
N \text { - кількість населення громади. }
$$

$$
K_{s}=Q_{f}^{*} K
$$

де $K_{s}-$ коефріцієнт стимуляції збільшення доходів;

$Q_{f}-$ фрактичний дохід села (селища) за відповідний період;

$K$ - коефіцієнт економічної спроможності села (селища).

Примітка 1: загальні доходи об'єднаної територіальної громади села (селища) враховують усі надходження за винятком:

- ПДФО сіл (селищ) (податок з доходів фізичних осіб);

- загальних доходів міської ради.

Примітка 2: при цьому сума бюджету розвитку затверджується радою громади. Якщо є потреба уточнити розподіл коштів (не раніше, ніж через півроку після початку бюджетного року за умови перевиконання бюджету не менш ніж на 5\%, відповідно до вимог Бюджетного кодексу), то до уваги береться коефіцієнт стимуляції збільшення доходів.

3 практичного погляду необхідно врахувати такі елементи під час розподілу фрінансових ресурсів ОТГ:

1. До подати розрахунок розподілу бюджетних коштів старостам сіл (селищ) відповідно до затвердженого бюджету об'єднаної територіальної громади.

2. Старостам відповідних сіл (селищ) відповідно до ст. 13 ЗУ «Про місцеве самоврядування в Україні» до провести громадські 
слухання щодо визначення пріоритетності раціонального використання бюджетних коштів.

3. Старостам відповідних сіл (селищ) до на сесії міської ради прозвітувати про результати ефективності використання бюджетних коштів.

Згідно з проведеними науковими дослідженнями встановлено, що розподіл бюджетних коштів у територіальній громаді буде здійснено залежно від площі території, чисельності сільських жителів а також фрактичних доходів села (селища) за відповідний період.

Проблема прозорості дій органів влади всіх рівнів сьогодні особливо актуальна, оскільки прозорість - основна умова запровадження якісно нового типу відносин між громадянами та органами виконавчої влади, а саме такого, за яким кожній людині було б забезпечено реальне додержання і захист належних їй прав і свобод у сорері діяльності цих органів.

Закон України «Про місцеве самоврядування в Україні» дає визначення і конкретизує методи залучення громадськості, зазначаючи, що: «громадяни України реалізують своє право на участь у місцевому самоврядуванні за належністю до відповідних територіальних громад». Ст. 7-13 цього Закону проголошують фрорми безпосередньої участі громадян через ініціювання і реалізацію місцевих ініціатив, збори громадян та громадські слухання. Так, одним 3 основних питань місцевого самоврядування, до якого необхідно залучати громадськість, є питання формування бюджету. Залежно від того, як фрормується бюджет самоврядної одиниці, яким є контроль за виконанням бюджету, можна говорити, наскільки $\epsilon$ повноцінною система самоврядування. Підвищення участі громадськості в місцевих бюджетних процесах та функціонуванні системи надання послуг надає низку переваг як для органів влади, так і для громадян.

Дотримання принципу публічності та прозорості на практиці $€$ запорукою надійності бюджету, оскільки це забезпечує довіру громадськості до державної бюджетної політики, сприяє збільшенню надходжень до бюджетів різних рівнів, а також посилює ефективність державного та громадського контролю над державними орінансами.

Також бюджетна прозорість дає громадянам змогу відчути себе повноправними споживачами максимального рівня суспільних послуг в обмін на сплачені податкові платежі. Іншими словами, в умовах доступності та прозорості фрінансової інфрормації громадськість здатна самостійно контролювати ефективність виконання.

Висновки 3 проведеного дослідження. 3'ясовано, що економічна категорія «фрінансова децентралізація» - фрінансові повноваження орга- нів регіонального рівня, незалежність та життєздатність органів місцевої влади.

Підтверджено, що ефрективності реформи фрінансової децентралізації можливо досягнути за умови одночасної зміни окремих її складників, а саме:

1) проведення бюджетної, податкової, адміністративно-територіальної реформ; 2) ресрормування місцевих органів представницької та виконавчої влади на місцях; 3) підвищення ролі малого і середнього підприємництва в ресормуванні місцевої економіки.

Перспективними напрямами подальших досліджень у цьому напрямі стануть питання сучасного стану та перспектив розвитку вищезазначених складників фрінансової децентралізації 3 урахуванням передового досвіду країн ЄС та можливостей його застосування в національній практиці.

\section{БІБЛІОГРАФІЧНИЙ СПИСОК:}

1. Арабчук Я.І. Фінансова децентралізація - основна складова спроможної громади. Теорія та практика державного управління і місцевого самоврядування. 2016. № 1. URL: http://nbuv.gov.ua/ UJRN/ Ttpdu_2016_1_20.2. (дата звернення: 10.10.2019).

2. Бюджетний Кодекс України: Верховна Рада України; Кодекс України від 08.07.2010 № 2456-VI (зі змінамиідоповненнями).URL:http://zakon.rada.gov.ua (дата звернення: 01.10.2019).

3. Лазутіна Л.О. Джерела фрормування місцевих бюджетів сільських територій в умовах децентралізаціï. URL: http://global-national.in.ua/archive/6-2015/150. pdf. (дата звернення: 03.09.2019).

4. Місцеве самоврядування в умовах децентралізації повноважень / Лелеченко А.П., Васильєва О.І., Куйбіда В.С., Ткачук А.Ф. Київ : 2017. 110 с.

5. Моніторинг процесу децентралізації влади та ресрормування місцевого самоврядування. URL: http://decentralization.gov.ua/monitoring2017_10_ua. (дата звернення:14.10. 2019).

6. Розвиток бюджетної децентралізації в Україні. Київ : НАН України, ДУ «Ін.-т екон. та прогнозув. НАН України» 2016. 70 с.

7. Набатова Ю.О. Формування місцевих бюджетів в умовах децентралізації фрінансових ресурсів. Ефективна економіка. 2015. № 5. URL: http://www.economy.nayka.com.ua/?op=1\&z=4100. (дата звернення: 26.08.2019).

8. Осипенко С.О. Фінансова децентралізація: ефрективність реалізації на місцевому рівні: $3 б$. наукових праць Таврійського державного агротехнологічного університету (економічні науки). 2013. № 4(24). С. 17-81.

9. Патицька Х.О. Фінансова децентралізація як основа формування самодостатніх територіальних громад. URL: http://www.economy.nayka.com.ua/ op=1\&z=4412. (дата звернення: 14.08.2019).

10. Слободянюк Н.О. Проблеми формування дохідної частини місцевих бюджетів в умовах фрінансової децентралізації. Економіка і суспільство. 2016. Вип. 2. С. 611-616. 


\section{REFERENCES:}

1. Arabchuk Ja.I. (2016) Finansova decentralizacija - osnovna skladova spromozhnoji ghromady [Financial decentralization is a key component of a prosperous community]. Teorija ta praktyka derzhavnogho upravlinnja i miscevogho samovrjaduvannja [The theory and practice of public administration and local self-government]. vol. 1. Available at: http://nbuv.gov.ua/ UJRN/ Ttpdu_2016_1_20. 2. (accessed 10 October 2019).

2. Bjudzhetnyj Kodeks Ukrajiny (2010) Verkhovna Rada Ukrajiny [Budget Code of Ukraine]. Kodeks Ukrajiny vid 08.07.2010 \# 2456-VI (zi zminamy i dopovnennjamy). Available at: http://zakon.rada.gov.ua (accessed 01 October 2019).

3. Lazutina L.O. Dzherela formuvannja miscevykh bjudzhetiv siljsjkykh terytorij v umovakh decentralizaciji [Sources of formation of local budgets of rural territories in conditions of decentralization]. Available at: http:// global-national.in.ua/archive/6-2015/150.pdf. (accessed 03 September 2019).

4. Lelechenko A.P., Vasyljjeva O.I., Kujbida V.S., Tkachuk A. F. (2017) Misceve samovrjaduvannja v umovakh decentralizaciji povnovazhenj [Local self-government under conditions of decentralization of powers] Kyjiv.

5. Monitoryngh procesu decentralizaciji vlady ta reformuvannja miscevogho samovrjaduvannja [Monitoring the decentralization process and reforming local selfgovernment] Available at: http://decentralization.gov.ua/ monitoring2017_10_ua. (accessed 4 October 2019).
6. Rozvytok bjudzhetnoji decentralizaciji v Ukrajini (2016) [Development of fiscal decentralization in Ukraine]. Kiev: NAS of Ukraine, State Institution «Institute of Economics. and predicted. NAS of Ukraine".

7. Nabatova Ju.O. (2015) Formuvannja miscevykh bjudzhetiv $v$ umovakh decentralizaciji finansovykh resursiv [Formation of local budgets in the conditions of decentralization of financial resources] Efektyvna ekonomika [An efficient economy]. no. 5. Available at: http://www.economy.nayka.com.ua/op=1\&z=4100. (accessed 26 August 2019).

8. Osypenko S.O. (2013) Finansova decentralizacija: efektyvnistj realizaciji na miscevomu rivni [Financial Decentralization: Effective Local Implementation]: $z b$. naukovykh pracj Tavrijsjkogho derzhavnogho aghrotekhnologhichnogho universytetu (ekonomichni nauky) [Coll. scientific works of the Taurida State Agrotechnological University (economic sciences). no. 4(24). pp. 176-181.

9. Patycjka Kh.O. Finansova decentralizacija jak osnova formuvannja samodostatnikh terytorialjnykh ghromad [Financial decentralization as a basis for the formation of self-sufficient territorial communities] Available at: http://www.economy.nayka.com.ual ?op $=1 \& z=4412$ (accessed 14 August 2019).

10. Slobodjanjuk N.O. (2016) Problemy formuvannja dokhidnoji chastyny miscevykh bjudzhetiv $v$ umovakh finansovoji decentralizaciji [Problems of formation of revenue part of local budgets in the conditions of financial decentralization]. Ekonomika $i$ suspiljstvo. vol. 2, pp. 611-616. 


\section{Vivchar Oksana \\ Doctor of Economic Sciences, Associate Professor, Professor at Department of Economic Security and Financial Investigation Ternopil National Economic University \\ Redkva Okana \\ Candidate of Economic Sciences, Instructor Technical College \\ Ternopil Ivan Puluj National Technical University \\ Garmatiuk Oksana \\ Candidate of Economic Sciences, Senior Lecturer at Department of Management and Administration Ternopil Ivan Puluj National Technical University}

\section{ESSENTIAL INTENTIONAL CHARACTERISTICS OF ORGANIZATIONAL AND ECONOMIC MECHANISM OF DISTRIBUTION OF FINANCIAL RESOURCES OF UNITED TERRITORIAL COMMUNITY: A COMPARATIVE-ANALYTICAL APPROACH IN THE CONTEXT OF SECURITY}

The purpose of the article. Since the reform of financial decentralization is not yet complete, the problem of optimization, revenue and expenditure of local budgets in terms of economic security is unresolved, and the issue of financial decentralization efficiency is marked by fragmentation of the study of theoretical, evolutionary and practical aspects due to the imperfection and constant changes of tax and budgetary legislation, there is an obvious need for further research towards comparative analytical approaches in the context of security studies and the mechanism for the distribution of financial resources of the united territorial communities. The purpose of the article is to investigate the current problems of using budget funds at the regional level, namely: to identify such an economic category as "financial decentralization", to search for sources of filling and rational, transparent use of the local budget.

Methodology. The study is based on the design method. In order to ensure equality and transparency of the organizational and economic mechanism of distribution of financial resources of the united territorial community, we have created two projects of the algorithm for calculating the budget of each village.

Results. One of the main issues of local self-government that the public needs to be involved in is budgeting. Depending on how the budget of the self-government unit is formed, which is the control over the execution of the budget, it is possible to say how full the self-government system is. Increasing public participation in local budgetary processes and the functioning of the service delivery system ensures public confidence in state budgetary policies, contributes to increased levels of budgeting at various levels.

When planning the development of community infrastructure, it is very important to identify the real needs of residents. That is why in the united territorial community there is a need to solve the problem of equitable distribution of budgetary funds among the settlements that are part of the united community. It is necessary to solve this problem collectively, and it is the scientific approach of applying the algorithm for calculating the budget of each village that ensures the fairness, clarity and transparency of the organizational and economic mechanism.

In order to ensure equality and financial autonomy, the following important concepts, such as community development budget (B), rural development budget (B'), were taken into account when creating the formula for allocating rural development budgets; community population $(\mathrm{N})$; population of the village $(\mathrm{n})$; expenditures per 1 inhabitant of the village (qo); factor of economic capacity of the village (K); revenue enhancement factor (Ks); village income for the relevant period (Qf). distribution of financial resources of the united territorial community.

Practical implications. Let's pay particular attention to the importance of adhering to the principle of publicity, fairness and transparency in practice, which is a guarantee of budgetary certainty. Our algorithms for calculating the budget of each village provide fairness, clarity and transparency of the organizational and economic mechanism, which in turn will allow citizens to feel full consumers of the maximum level of public services in exchange for paid tax payments, and this will ensure public confidence in the public increase budget revenues at different levels, and increase the efficiency of state and public control over public finances.

Value/originality. In our work we have considered the issues of the effectiveness of the reform of financial decentralization, which can be achieved with the simultaneous change of its individual components, namely: 1) budgetary, tax, administrative-territorial reforms; 2) reform of local bodies of representative and executive power on the ground; 3 ) increasing the role of small and medium-sized enterprises in reforming the local economy. Prospective directions for further research in this area will be the issues of the current state and prospects of development of the abovementioned components of financial decentralization, taking into account the best practices of EU countries and the possibilities of its application in national practice. 